\title{
Epidemiological characteristics of cases of death from tuberculosis and vulnerable territories ${ }^{1}$
}

\author{
Mellina Yamamura² \\ Marcelino Santos-Neto ${ }^{3}$ \\ Rebeca Augusto Neman dos Santos ${ }^{4}$ \\ Maria Concebida da Cunha Garcia ${ }^{2}$ \\ Jordana de Almeida Nogueira ${ }^{5}$ \\ Ricardo Alexandre Arcêncio ${ }^{6}$
}

Objective: to characterize the differences in the clinical and epidemiological profile of cases of death that had tuberculosis as an immediate or associated cause, and to analyze the spatial distribution of the cases of death from tuberculosis within the territories of Ribeirão Preto, Brazil. Method: an ecological study, in which the population consisted of 114 cases of death from tuberculosis. Bivariate analysis was carried out, as well as point density analysis, defined with the Kernel estimate. Results: of the cases of death from tuberculosis, 50 were the immediate cause and 64 an associated cause. Age $(p=.008)$ and sector responsible for the death certificate $(p=.003)$ were the variables that presented statistically significant associations with the cause of death. The spatial distribution, in both events, did not occur randomly, forming clusters in areas of the municipality. Conclusion: the difference in the profiles of the cases of death from tuberculosis, as a basic cause and as an associated cause, was governed by the age and the sector responsible for the completion of the death certificate. The non-randomness of the spatial distribution of the cases suggests areas that are vulnerable to these events. Knowing these areas can contribute to the choice of disease control strategies.

Descriptors: Tuberculosis; Mortality; Health Information Systems; Geographic Information Systems.

\footnotetext{
${ }^{1}$ Paper extracted from doctoral dissertation "Spatial analysis of deaths, hospitalizations by tuberculosis and relationship with social indicators in Ribeirão Preto (SP)", presented to Escola de Enfermagem de Ribeirão Preto, Universidade de São Paulo, PAHO/WHO Collaborating Centre for Nursing Research Development, Ribeirão Preto, SP, Brazil. Supported by Fundação de Amparo à Pesquisa do Estado de São Paulo (FAPESP), Brazil, process \# 2011/22834-5.

2 Doctoral student, Escola de Enfermagem de Ribeirão Preto, Universidade de São Paulo, PAHO/WHO Collaborating Centre for Nursing Research Development, Ribeirão Preto, SP, Brazil. Scholarship holder from Fundação de Amparo à Pesquisa do Estado de São Paulo (FAPESP), Brazil.

${ }_{3}^{3}$ PhD, Assistant Professor, Centro de Ciências Sociais, Saúde e Tecnologia, Universidade Federal do Maranhão, Imperatriz, MA, Brazil.

${ }^{4}$ Undergraduate student in Nursing, Escola de Enfermagem de Ribeirão Preto, Universidade de São Paulo, PAHO/WHO Collaborating Centre for Nursing Research Development, Ribeirão Preto, SP, Brazil. Scholarship holder from Conselho Nacional de Desenvolvimento Científico e Tecnológico (CNPq), Brazil.

${ }_{5}^{5}$ PhD, Associate Professor, Departamento de Enfermagem Clínica, Universidade Federal da Paraíba, João Pessoa, PB, Brazil.

${ }^{6}$ Post-doctoral fellow, Faculdade de Saúde Pública, Universidade de São Paulo, São Paulo, SP, Brazil. Professor, Escola de Enfermagem de Ribeirão Preto, Universidade de São Paulo, PAHO/WHO Collaborating Centre for Nursing Research Development, Ribeirão Preto, SP, Brazil.
}

Corresponding Author:

Ricardo Alexandre Arcêncio

Universidade de São Paulo. Escola de Enfermagem de Ribeirão Preto

Departamento Materno-Infantil e Saúde Pública

Av. Bandeirantes, 3900

Bairro: Monte Alegre

CEP: 14040-902, Ribeirão Preto, SP, Brasil

E-mail: ricardo@eerp.usp.br
Copyright @ 2015 Revista Latino-Americana de Enfermagem This is an Open Access article distributed under the terms of the Creative Commons Attribution Non-Commercial License (CC BY-NC).

This license lets others distribute, remix, tweak, and build upon your work non-commercially, and although their new works must also acknowledge you and be non-commercial, they don't have to license their derivative works on the same terms. 


\section{Introduction}

Defined as one of the ten leading causes of death worldwide, Tuberculosis (TB) affected approximately 8.6 million people in the year 2012, with 1.3 million dying from the disease, demonstrating the gravity of the phenomenon in the global context ${ }^{(1)}$.

Despite a global decline of $23.4 \%$ in TB deaths over 10 years, Brazil still recorded 3.1 deaths per 100,000 inhabitants in 2012 and 2.4 in 2010 . There is the challenge of a reduction of $95 \%$ of these deaths by 2035, in accordance with the target recently adopted by the World Health Organization (WHO) ${ }^{(1)}$.

Also in this context it is worth noting that death from TB is an event regarded as unjustifiable and unacceptable, since the diagnostic methods are relatively simple, with low complexity diagnostics, such as sputum smear microscopy, and free treatment provided by the Brazilian Nation Health System (SUS), which is $99.9 \%$ effective $^{(2)}$.

Studies on TB deaths should be considered, due to the possibility of tracing the profile of the population affected by the disease, accompanying the individual in different situations, as well as providing additional analysis regarding the surveillance of cases and patient care $^{(3)}$.

These types of studies have been conducted in different parts of Brazil(3-5), showing that cases of deaths are consequences of health inequalities that are imposed on that service systems of the area. A report published by the Pan American Health Organization(6) cites Brazil as one of the leaders on the continent in terms of social inequalities.

According to the authors ${ }^{(7)}$, social inequalities in health lead to a delay in diagnoses, abandonment and failure of the treatment, the emergence of multidrug resistant TB and cases of death. It should also be noted that access to health services varies from region to region, therefore, the risk of disease and consequently its prognosis or outcome also present variations ${ }^{(8-9)}$. The literature indicates that deaths from TB, in certain territories, are more prevalent in areas with social problems and that lack assistance ${ }^{(9)}$, however, there are few studies(10-11) that show this, which is important for addressing the problem.

Considering the importance of equipping managers and employees of the areas most afflicted by TB, highlighting the regions of access inequality, the aim of this study was to characterize the differences in the clinical and epidemiological profile of deaths that had TB as the immediate or associated cause and to analyze the spatial distribution of the cases of death from TB in the territories of Ribeirão Preto.

\section{Method}

This was an ecological study conducted in the municipality of Ribeirão Preto, situated in the northeast of São Paulo state, $313 \mathrm{~km}$ from the capital and with a population of 604,682 inhabitants. The municipality is part of the group that present high levels of social and economic indicators, and, according to data from the State Foundation System of Data Analysis(12), referring to the census data of 2000 , with a rate of life expectancy at birth of 74.80 years, a municipal Human Development Index of 0.733 , a social exclusion index of approximately 0.67 , a poverty incidence of $11.75 \%$ and Gini Index of 0.45 . In the 2010 edition of the São Paulo Index of Social Responsibility, Ribeirão Preto ranked in Group 2, which includes the municipalities that, despite presenting high levels of wealth, do not display good social indicators, exceeding the mean of the state of São Paulo in longevity and education scores ${ }^{(12)}$.

The research population was composed of all 114 cases of death from TB registered in the Mortality Information System (MIS), for the period from 2006 to 2012. Data collection was carried out in the Epidemiological Surveillance Division of the Municipal Health Department of Ribeirão Preto. In the data selection process, the death certificates (DCs) considered were those of residents of the urban area of Ribeirão Preto, that had, regarding both the immediate cause and the associated cause, a classification of A15.0 to A19.9 in the International Classification of Diseases version 10 (ICD-10), encompassing all clinical forms of TB.

Considering the sociodemographic characteristics, the variables of interest were age, gender, race/color, marital status, education and occupation. The variables that encompassed the epidemiological profile were immediate cause and associated cause of death, place in which death occurred, medical care, complementary examination, surgery, autopsy and person responsible for completing the DC.

For the bivariate analysis, performed using the Statistica version 12 software, the crossing of the dependent variable, TB immediate cause (yes or no), with the independent variables (sociodemographic characteristics and other epidemiological characteristics) was considered. For the age variable (continuous) measures of central tendency (mean, median) and 
maximum and minimum values were calculated, with this also being categorized from the median, so that the age was ranked above or below the value obtained. Subsequently, the chi-square test of proportions was applied, with Yates correction or Fisher's exact test, when necessary, setting the type I error probability at $5 \%$. It is worth clarifying that the ignored or incomplete deaths records were excluded from this step.

For the identification of the areas vulnerable to cases of death, the geocoding was initially carried out using the TerraView 4.22 software considering the StreetBase ${ }^{\circledR}$ digital map of street address segments in projection UTM/WGS84, available in the Shapefile format, acquired via the Imagem Soluções de Inteligência Geográfica company. In this stage, considering the standardization and the equalization of the addresses of the resident cases, the inclusion criteria were occurrence in urban areas and full address.

Subsequently, the technique of point density analysis, defined with the Kernel estimate, was used, which constitutes exploratory interpolation, generating a surface density to identify hot or vulnerable areas. Considering the distance of $1,000 \mathrm{~m}$, thematic maps of density distribution of the deaths were generated using the ArcGIS 10.2 software.
The project was approved by the Research Ethics Committee of the Ribeirão Preto College of Nursing, with the Certificate of Presentation for Ethics Assessment (CAAE) No. 09708612.7.0000.5393.

\section{Results}

In the period from 2006 to 2012, 114 deaths with ICD A15.0 to A19.9 were reported, of which 50 had TB as the immediate cause and 64 had TB as an associated cause. The minimum age of cases was 27 years and the maximum 91 years, with mean and median of 52 years.

According to Table 1, the majority of the cases of death occurred in males of white race/color. With regard to the epidemiological characteristics, $93(81.58 \%)$ cases of death occurred in the hospital context and 61 (53.51\%) underwent autopsy to confirm the cause of death, however, the majority of the DCs were not completed by the Death Verification Service (SVO) but by other services ( $n=39 ; 34.21 \%)$.

Table 1 presents the results of the bivariate analysis. Age had a statistically significant association with the cause of death $(p=.008)$, showing that people over the age of 52 years had TB as the immediate cause of death, while in those younger (under 52 years) the disease was associated with the event.

Table 1 - Distribution of the sociodemographic characteristics of the cases of death from tuberculosis, according to immediate causes or not. Ribeirão Preto, SP, Brazil, 2006/2012

\begin{tabular}{|c|c|c|c|c|c|c|c|}
\hline \multirow{2}{*}{ Variables } & \multirow{2}{*}{ Total } & \multirow{2}{*}{ (\%) } & \multicolumn{2}{|c|}{ Immediate cause } & \multicolumn{2}{|c|}{ Associated cause } & \multirow{2}{*}{$P$ value } \\
\hline & & & $\mathbf{n}$ & $(\%)$ & $\mathbf{n}$ & $(\%)$ & \\
\hline \multicolumn{8}{|l|}{ Age, years $(n=114)$} \\
\hline$\leq 52$ & 57 & 50.00 & 18 & 15.79 & 39 & 34.21 & $.008^{*}$ \\
\hline$>52$ & 57 & 50.00 & 32 & 28.07 & 25 & 21.93 & \\
\hline \multicolumn{8}{|l|}{ Gender $(n=114)$} \\
\hline Male & 92 & 73.60 & 37 & 32.46 & 55 & 48.25 & .109 \\
\hline Female & 22 & 26.40 & 13 & 11.40 & 9 & 7.89 & \\
\hline \multicolumn{8}{|l|}{ Race/color $(n=108)$} \\
\hline White & 71 & 62.28 & 25 & 23.15 & 46 & 42.59 & .162 \\
\hline Black & 36 & 31.58 & 18 & 16.67 & 18 & 16.67 & \\
\hline Yellow & 1 & 0.88 & 1 & 0.93 & 0 & 0.00 & \\
\hline \multicolumn{8}{|l|}{ Marital status $(n=97)$} \\
\hline Single & 51 & 44.74 & 20 & 20.62 & 31 & 31.96 & .669 \\
\hline Married & 35 & 30.70 & 17 & 17.53 & 18 & 18.56 & \\
\hline Widowed & 6 & 5.26 & 2 & 2.06 & 4 & 4.12 & \\
\hline Separated /divorced & 5 & 4.39 & 3 & 3.09 & 2 & 2.06 & \\
\hline \multicolumn{8}{|c|}{ Schooling in years of study $(n=48)$} \\
\hline None & 2 & 1.75 & 2 & 4.17 & 0 & 0.00 & .165 \\
\hline $1-3$ & 5 & 4.39 & 2 & 4.17 & 3 & 6.25 & \\
\hline $4-7$ & 29 & 25.44 & 13 & 27.08 & 16 & 33.33 & \\
\hline $8-11$ & 9 & 7.89 & 2 & 4.17 & 7 & 14.58 & \\
\hline$>12$ & 3 & 2.63 & 0 & 0.00 & 3 & 6.25 & \\
\hline
\end{tabular}


Table 1 - (continuation)

\begin{tabular}{|c|c|c|c|c|c|c|c|}
\hline \multirow{2}{*}{ Variables } & \multirow{2}{*}{ Total } & \multirow{2}{*}{ (\%) } & \multicolumn{2}{|c|}{ Immediate cause } & \multicolumn{2}{|c|}{ Associated cause } & \multirow{2}{*}{$P$ value } \\
\hline & & & $\mathbf{n}$ & $(\%)$ & $\mathrm{n}$ & $(\%)$ & \\
\hline \multicolumn{8}{|l|}{ Occupation $(n=48)$} \\
\hline Retired/pensioner & 23 & 20.17 & 12 & 25.00 & 11 & 22.92 & .741 \\
\hline Housewife & 4 & 3.51 & 2 & 4.17 & 2 & 4.17 & \\
\hline General services & 17 & 14.91 & 7 & 14.58 & 10 & 20.83 & \\
\hline Other & 4 & 3.51 & 1 & 2.08 & 3 & 6.25 & \\
\hline \multicolumn{8}{|l|}{ Place of occurrence $(n=114)$} \\
\hline Hospital & 93 & 81.58 & 36 & 31.58 & 57 & 50.00 & .075 \\
\hline Other health facilities & 13 & 11.40 & 10 & 8.77 & 3 & 2.63 & \\
\hline Home & 6 & 5.26 & 3 & 2.63 & 3 & 2.63 & \\
\hline Other & 2 & 1.75 & 1 & 0.88 & 1 & 0.88 & \\
\hline \multicolumn{8}{|l|}{ Medical care $(n=88)$} \\
\hline Yes & 83 & 72.81 & 32 & 36.36 & 51 & 57.95 & .405 \\
\hline No & 5 & 4.39 & 1 & 1.14 & 4 & 4.55 & \\
\hline \multicolumn{8}{|l|}{$\begin{array}{l}\text { Complementary examination } \\
(n=63)\end{array}$} \\
\hline Yes & 53 & 84.13 & 19 & 30.16 & 34 & 53.97 & .721 \\
\hline No & 10 & 15.87 & 3 & 4.76 & 7 & 11.11 & \\
\hline \multicolumn{8}{|l|}{ Surgery $(n=67)$} \\
\hline Yes & 7 & 6.14 & 2 & 2.99 & 5 & 7.46 & .557 \\
\hline No & 60 & 52.63 & 24 & 35.82 & 36 & 53.73 & \\
\hline \multicolumn{8}{|l|}{ Autopsy $(n=109)$} \\
\hline Yes & 61 & 53.51 & 27 & 24.77 & 34 & 31.19 & .623 \\
\hline No & 48 & 42.10 & 19 & 17.43 & 29 & 26.61 & \\
\hline \multicolumn{8}{|c|}{ Completion of the Death Certificate $(n=111)$} \\
\hline Death Verification Service & 26 & 22.80 & 19 & 17.12 & 7 & 6.31 & $.003^{*}$ \\
\hline Attending physician & 28 & 24.56 & 12 & 10.81 & 16 & 14.41 & \\
\hline Substitute physician & 18 & 15.79 & 6 & 5.41 & 12 & 10.81 & \\
\hline Other & 39 & 34.21 & 11 & 9.91 & 28 & 25.23 & \\
\hline
\end{tabular}

$* \mathrm{P}<.05$

Another variable that also showed a statistically significant association with the cause of death was the sector or professional responsible for the death certificate $(p=.003)$, with the highest proportion of people that had TB as the immediate cause issued by the SVO. Regarding the deaths in which TB was an associated cause, there were higher proportions of deaths certificates issued by services other than the SVO.
Concerning the clinical form, among the cases of death with TB as the immediate cause, as well as those with it as an associated cause, pulmonary TB, without mention of bacteriological or histological confirmation examination, was prevalent. Table 2 presents the frequencies of the clinical forms of TB found in the investigation.

Table 2 - Distribution of the deaths from TB as the immediate cause and an associated cause, according to the clinical form. Ribeirão Preto, SP, Brazil, 2006/2012

\begin{tabular}{|c|c|c|c|c|c|}
\hline \multirow{2}{*}{ Code } & \multirow{2}{*}{ Definition } & \multicolumn{2}{|c|}{ Immediate cause } & \multicolumn{2}{|c|}{ Associated cause } \\
\hline & & n & $\%$ & n & $\%$ \\
\hline A15.2 & Pulmonary tuberculosis with histological confirmation & 18 & 36.0 & 15 & 23.0 \\
\hline A15.3 & Pulmonary tuberculosis, with confirmation by unspecified means & 1 & 2.0 & 1 & 1.5 \\
\hline A16.2 & $\begin{array}{l}\text { Pulmonary tuberculosis, without mention of bacteriological or histological } \\
\text { confirmation }\end{array}$ & 25 & 50.0 & 26 & 41.0 \\
\hline A16.5 & $\begin{array}{l}\text { Tuberculosis pleurisy, without mention of bacteriological or histological } \\
\text { confirmation }\end{array}$ & 1 & 2.0 & 3 & 4.7 \\
\hline A16.9 & $\begin{array}{l}\text { Respiratory tuberculosis, unspecified, without mention of bacteriological or } \\
\text { histological confirmation }\end{array}$ & 0 & 0 & 4 & 6.2 \\
\hline A17.8 & Other tuberculosis of the nervous system & 1 & 2.0 & 2 & 3.1 \\
\hline A17.9 & Tuberculosis of the nervous system, unspecified & 0 & 0 & 0 & 0 \\
\hline A18.0 & Tuberculosis of bones and joints & 1 & 2.0 & 0 & 0 \\
\hline
\end{tabular}


Table 2 - (continuation)

\begin{tabular}{llcccc}
\hline \multirow{2}{*}{ Code } & Definition & \multicolumn{2}{c}{ Immediate cause } & \multicolumn{2}{c}{ Associated cause } \\
\cline { 3 - 6 } & & $\mathbf{n}$ & $\%$ & $\mathbf{n}$ & $\%$ \\
\hline A18.1 & Tuberculosis of the genitourinary system & 0 & 0 & 1 & 1.5 \\
A18.2 & Tuberculous peripheral lymphadenopathy & 0 & 0 & 2 & 3.1 \\
A18.8 & Tuberculosis of other specified organs & 1 & 2.0 & 0 & 0 \\
A19.0 & Acute miliary tuberculosis of a single specified site & 0 & 0 & 2 & 3.1 \\
A19.8 & Other miliary tuberculosis & 1 & 2.0 & 0 & 0 \\
A19.9 & Miliary tuberculosis, unspecified & 1 & 2.0 & 8 & 12.5 \\
Total & & 50 & 100 & 64 & 100 \\
\hline
\end{tabular}

In spatial analysis, it was possible to geocode 102 ( $89 \%$ ) of the 114 total cases of death considered in the study. The losses were due to the fact that eight cases were located in rural areas and four presented inconsistencies related to the address. Figures 1 and 2 present the thematic maps of the density of deaths with TB as the immediate cause and of those with TB as an associated cause, respectively, within the urban area of Ribeirão Preto.
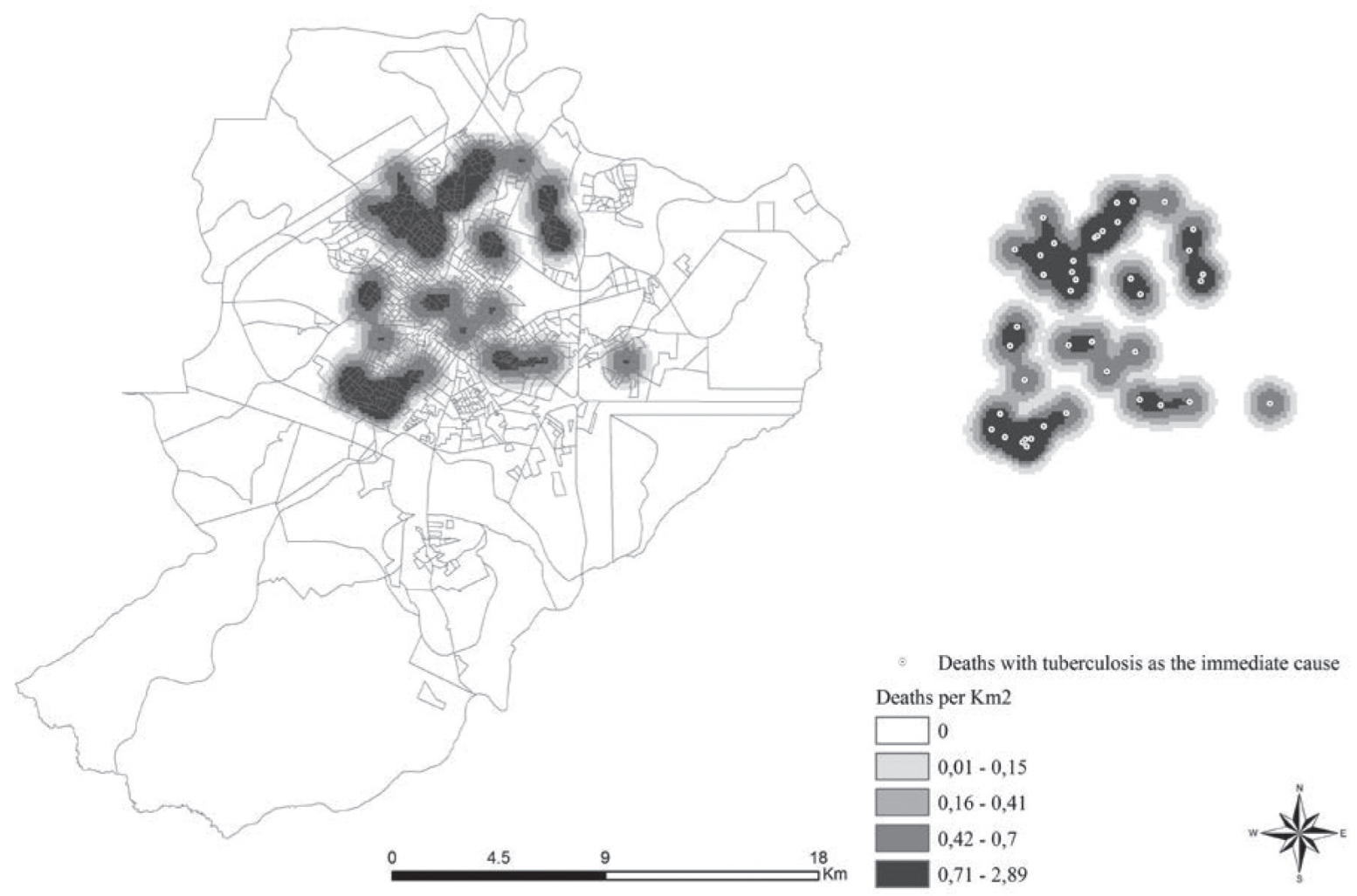

Figure 1 - Map of the density distribution of cases of deaths from tuberculosis as the immediate cause. Ribeirão Preto, SP, Brazil, 2006/2012

Figure 1 shows a higher density of deaths with TB as the immediate cause in the census sectors covered by the western and northern health districts, and a slight focus in the eastern health district coverage area. The higher density of the cases of death with TB as an associated cause (Figure 2) was also in the area of the western health district, however, extended to the census sectors of the areas covered by the central and southern health districts of the city, showing different areas of density to the cases of death with TB as the immediate cause, however, there is a heterogeneous distribution on both maps. 

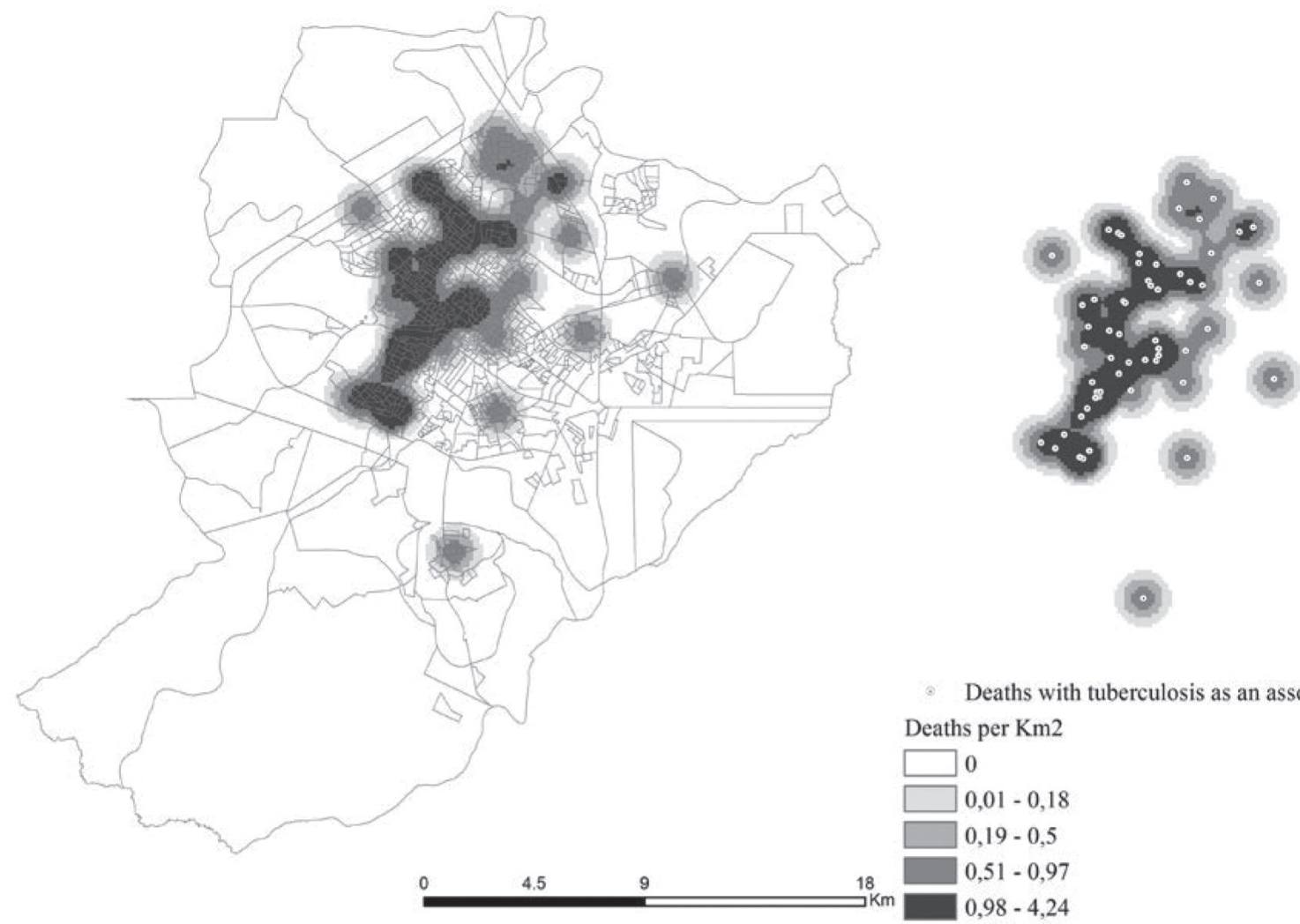

Figure 2 - Map of the density distribution of cases of deaths from tuberculosis as the immediate cause. Ribeirão Preto, SP, Brazil, 2006/2012

\section{Discussion}

The results show that the median age of those who died from TB was 52 years, with the majority being single, male, of white race/color and with four to seven years of schooling, with these results being similar to those found in a study conducted in the state of São Paulo(13).

There was also no difference in the profile of the people that had TB as the immediate cause of death compared to those in which TB was an associated cause, except for the variables age and sector responsible for completion of the $\mathrm{DC}$. In relation to the latter variable, there were higher proportions of cases of death with TB as the immediate cause certified by the SVO.

Regarding the age of the cases of death from TB, it was observed that the younger individuals had TB as a cause associated with death. A study conducted in Malawi regarding the causes of death with HIV provides a possible explanation for this finding. It found that TB was the second most common cause of death among these patients, and also that young people were more likely to progress to death from TB than people over 60 years of age, since the latter were less affected by the HIV pandemic (14).

Another factor that may also contribute to the interpretation of these results comes from a the study carried out in Campinas, SP, which also showed differences between age groups, in which the cases of death with TB as the immediate cause occurred in people over the age of 50 years and cases of death with AIDS as the immediate cause in people aged between 21 and 40 years $^{(15)}$.

Considering that TB is the most common opportunistic infection in patients infected with Human Immunodeficiency Virus (HIV), being responsible for $26 \%$ of deaths in AIDS cases ${ }^{(16)}$, there are reasons that lead the authors to assume an influence of HIV in cases of deaths that had TB as an associated cause. In the municipality under study the incidence rate for HIV was 26.13 per 100,000 inhabitants in 2012 and among the 
TB-HIV co-infected patients, the percentage of death was $32.8 \%^{(17)}$.

It should be noted that the cases of death in which TB was an associated cause have a multicausal explanation and there may be interference from other causes, including HIV (ICD B20.0), however, to investigate the other associated causes of death, other than TB, was not the aim of this study, although this would be worth investigation.

To consider only a single cause of death can be an arbitrary selection, since the associated causes are excluded from the tabulations, however, are also causes that play an important factor in the chain of morbid events that contribute to death(18).

Although the use of the concept of immediate cause is relevant for mortality studies, this approach creates limitations due to loss of information when the explanation of death is multi-causal. Furthermore, the pattern of the causes of death is somewhat linked with quality, because this may reflect the availability of the medical care provided to the population and the characteristics of the DC completion ${ }^{(19)}$.

In this sense, the SVOs appear as co-participants in this data qualification, because they can minimize the poorly defined causes ${ }^{(19)}$, however, the high number of referrals, specifically in the case of $T B$, can represent great disarticulation between the treatment units and the disease surveillance system ${ }^{(20)}$.

Another result that was related to the quality of the TB surveillance system was the number of cases of death, both as a immediate cause and an associated cause, with ICD A16.2, which refers to pulmonary TB, without mention of bacteriological or histological confirmation, a situation similar to that found in studies in Campo Grande, $\mathrm{MS}^{(4)}$, Rio de Janeiro, $\mathrm{RJ}^{(5)}$ and Sao Luis, $M A^{(9)}$. According to the authors of the first study(4), the interrelating of databases, for example the MIS and the Information System for Notifiable Diseases, enables the reclassification of some cases, including those in which there was no bacteriological or histological confirmation.

It should also be noted that among the clinical forms of TB, pulmonary TB deserves more emphasis, because it is transmissible and requires immediate intervention in order to affect the chain of transmission; furthermore, it is on the list of preventable causes of deaths, given that, if appropriate actions of health promotion, protection and recovery were instituted for individuals and families by the local health systems, these events would not occur(21).
Considering death from TB to be a sentinel event, which characterizes failures in the process of prevention, diagnosis and treatment of the disease ${ }^{(21)}$, it appears to not only reflect the organization and quality of the health services, but also the unequal distribution of health power, resources and technologies among social groups, resulting in social inequality in health ${ }^{(22)}$ and affecting, directly and indirectly, the exacerbation of some health conditions.

Corroborating this situation, it was found that the spatial distribution, of both the cases of TB as the immediate cause of death and as an associated cause, did not occur at random, seeming to form clusters in some areas of the municipality investigated, suggesting areas vulnerable to the occurrence of these events. These territories have been highlighted in other studies, as they constitute critical areas in terms of incidence and prevalence of $\mathrm{TB}^{(22)}$.

Other authors ${ }^{(23)}$ have also highlighted the vulnerability of areas of Ribeirão Preto, classifying them into lower, intermediate and higher socioeconomic levels, noting that the higher incidence of HIV/TB co-infection has been in the intermediate socioeconomic level areas. Considering this classification performed by the authors $^{(23)}$, the data of the present study demonstrate that the occurrence of deaths from TB, both as an associated and immediate cause, were concentrated in lower and intermediate socioeconomic status areas.

Knowing the priority sites for TB control, as demonstrated in this and other studies ${ }^{(9,22-23)}$, can assist in public management, with subsidies for choosing specific strategies and interventions directed toward the most vulnerable populations, as well as in reducing social inequities in health.

In this context, the resulting maps of the spatial analyzes performed in this study show the risk areas ${ }^{(24)}$. According to the results, these areas, both in the cases of death from TB as the immediate cause and as an associated cause, which present little difference in the formation of clusters (darker areas of the maps), are places that possibly experience greater inequality of access to health education resources, income distribution, basic sanitation, education and other standard constituent of life of the population, favoring the risk of illness ${ }^{(25)}$.

The lighter areas of Figures 1 and 2 could then represent areas of protection from the disease and consequently death from TB, therefore presenting the need for further studies to explain the occurrence of these cases of death, taking into account the social 
determinants of health, both individually and collectively, since an ecological study can present limitations concerning the collinearity of the data.

Another limitation to be highlighted relates to the use of secondary data, which may have created bias in the study, due to the presence of gaps or incomplete data. It should also be noted that for the spatial analyses, only the cases of death of people living in the urban area of the municipality were considered, however the literature ${ }^{(9)}$ has shown that people living in rural areas may experience more difficulty in accessing health services and consequently a less satisfactory outcome or prognosis, therefore, it would be interesting to include these areas in future studies.

\section{Conclusion}

The difference in the profiles of the cases of death from TB as the immediate cause and as an associated cause, was governed by the age and by the sector responsible for the completion of the DC. The spatial distribution, of the cases of TB both as the immediate cause of death and as an associated cause, did not occur at random, seeming to form clusters in some regions of the municipality investigated, suggesting areas vulnerable to the occurrence of these events.

Areas with the formation of clusters are possibly places that experience greater inequality of access to health education resources, income distribution, basic sanitation and other constituents of the life pattern of the population that favor the risk of illness.

Knowing the priority sites for TB control can assist in public management, with subsidies for choosing specific strategies and interventions directed toward the most vulnerable populations, as well as in reducing social inequities in health. However, there is a need to carry out further studies, which may explain the occurrence of these cases of death taking into consideration the social determinants of health.

\section{Acknowledgements}

The Municipal Health Department of Ribeirão Preto, Epidemiological Surveillance Division.

\section{References}

1. World Health Organization (WHO). Global strategy and targets for tuberculosis prevention, care and control after 2015. [Internet]. Geneva: WHO; 2014. 67th
World Health Assembly: 2014. [acesso 12 dez 2014]. Disponível em: http://www.who.int/tb/post2015_ TBstrategy.pdf?ua $=$

2. World Health Organization. The global plan to stop TB 2011-2015: transforming the fight towards elimination of tuberculosis - reprinted with changes, 2011. [Internet]. Geneva: WHO; 2010 [acesso 12 dez 2014]. Disponível em: http://whqlibdoc.who.int/ publications/2010/9789241500340_eng.pdf

3. Sousa LMO, Pinheiro RS. Óbitos e internações por tuberculose não notificados no município do Rio de Janeiro. Rev Saúde Pública. 2011;45(1):31-9.

4. Espindola LCD. Estudo da mortalidade por tuberculose em Campo Grande - MS, 2001 a 2008. Dissertação [mestrado]. 44 p. Rio de Janeiro: Escola Nacional de Saúde Pública Sergio Arouca da Fiocruz; 2010.

5. Selig L, Kritski AL, Cascão AM, Braga JU, Trajman A, Carvalho MG. Proposta de vigilância de óbitos por tuberculose em sistemas de informação. Rev Saúde Pública. 2010;44(6):1072-8.

6. Organização Pan-Americana de Saúde (OPAS). Health in the Americas, 2012. Brazil. Edition: Country Volume. OPAS-OMS [Internet]. Washington: OPAS; 2012 [acesso 12 dez 2014]. Disponível em: http://www.paho.org/ saludenlasamericas/index.php?option=com_docman\&ta sk=doc_view\&gid $=118 \&$ Itemid $=$

7. Hargreaves JR, Boccia D, Evans CA, Adato M, Petticrew M, Porter JDH. The Social Determinants of Tuberculosis: From Evidence to Action. Am J Public Health. 2011;101(4):654-62.

8. Yamamura M, Santos Neto M, Freitas IM, Rodrigues LBB, Popolin MP, Uchoa SAC, et al. Tuberculose e iniquidade social em saúde: uma análise ecológica utilizando técnicas estatísticas multivariadas, São Paulo, Brasil. Rev Panam Salud Publica. 2014;35(4):270-7.

9. Santos Neto M, Yamamura M, Garcia MCC, Popolin MP, Silveira TRS, Arcêncio RA. Análise espacial dos óbitos por tuberculose pulmonar em São Luís (MA). J Bras Pneumola. J Bras Pneumol. 2014;40(5):543-51.

10. Mota FF, Vieira-da-Silva LM, Paim JS, Costa MCN. Distribuição espacial da mortalidade por tuberculose em Salvador, Bahia, Brasil. Cad Saúde Pública. 2003;19(4):915-22.

11. Vicentin G, Santo AH, Carvalho MS. Mortalidade por tuberculose e indicadores sociais no município do Rio de Janeiro. Ciênc Saúde Coletiva. 2002;7(2):253-63.

12. Fundação Sistema Estadual de Análise de Dados. Informações dos municípios paulistas - IMP [Internet]. [acesso 25 fev 2015]. Disponível em: http://produtos. seade.gov.br/produtos/imp/ 
13. Santo AH, Pinheiro, CE, Jordani MS. Causas múltiplas de morte relacionadas à tuberculose no Estado de São Paulo, 1998. Rev Saúde Pública. 2003;37(6):714-21.

14. Chihana M, Floyd $S$, Molesworth A, Crampin AC, Kayuni N, Price A, et al. Adult mortality and probable cause of death in rural northern Malawi in the era of HIV treatment. Trop Med Int Health. 2012;17(8):74-83.

15. Oliveira HB, Marín-León L, Cardoso JC. Perfil de mortalidade de pacientes com tuberculose relacionada à comorbidade tuberculose-Aids. Rev Saúde Pública. 2004;38(4): 503-10.

16. Chang CC, Crane M, Zhou J, Mina M, Post JJ, Cameron BA, et al. HIV and co-infections. Immunol Rev. 2013;254(1):114-42.

17. Castrighini CC. Prevalência da coinfecção HIV/ tuberculose em indivíduos residentes no município de Ribeirão Preto - SP. Dissertação [mestrado]. 78 p. Ribeirão Preto (SP): Escola de Enfermagem de Ribeirão Preto da USP; 2014.

18. Santo AH. Potencial epidemiológico da utilização das causas múltiplas de morte por meio de suas menções nas declarações de óbito, Brasil, 2003. Rev Panam Salud Publica. 2007;22(3):178-86.

19. Campos D, Franca E, Loschi RH, Souza MFM. Uso da autópsia verbal na investigação de óbitos com causa mal definida em Minas Gerais, Brasil. Cad Saúde Pública. 2010;26(6):1221-33.

20. Mello MLR, Ishimoto $E$, Luís LFA, Santos ML, Barros VL, Moreira APC. A Vigilância de óbitos como integrante do controle da tuberculose na área da administração regional de saúde 3, Município de São Paulo, 1998. Centro de Vigilância Epidemiológica. Bol Informativo. 1999;14(56):3-7.

21. Malta DC, França E, Abreu DX, Oliveira $H$, Monteiro RA, Sardinha LMV, et al. Atualização da lista de causas de mortes evitáveis ( 5 a 74 anos de idade) por intervenções do Sistema Único de Saúde do Brasil. Epidemiol Serv Saúde. 2011;20(3):409-12.

22. Hino $P$, Cunha TN, Villa TCS, Santos CB. Perfil dos casos novos de tuberculose notificados em Ribeirão Preto (SP) no período de 2000 a 2006. Cienc Saúde Coletiva. 2011;16:1295-301.

23. Brunello MEF, Chiaravalloti Neto F, Arcêncio RA, Andrade RLP, Magnabosco GT, Villa TCS. Áreas de vulnerabilidade para co-infecção HIV-aids/TB em Ribeirão Preto, SP. Rev Saúde Pública. 2011;45(3):556-63.

24. Davies TM, Hazelton ML. Adaptive kernel estimation of spatial relative risk. Stat Med. 2010;29(23):2423-37. 25. Sena RR, Silva KL. Políticas e práticas de saúde rumo à eqüidade. Rev Esc Enferm USP. 2007;41(Spec):771-6. 